\title{
Eğitim Fakültesi Öğrencilerinin Akıllı Telefonlara Yönelik Algıları: Metafor Analizi ile Bir Değerlendirme
}

\section{The Metaphoric Perceptions of Education Faculty Students' Towards "Smartphones": An Evaluation with Metaphor Analysis}

\author{
Hicran Çetin Gündüz ${ }^{1}$ Zeynep Kızıl Aslan ${ }^{2}$ Cansu Hazal Güçlü ${ }^{3}$
}

Özet

Bu çalışmanın amacı eğitim fakültesi öğrencilerinin akıllı telefonlara ilişkin algılarını incelemektir. Nitel araştırma yönteminin kullanıldı ̆̆ çalışmada metaforlardan yararlanılmış ve veriler içerik analizi ile incelenmiştir. Çalışmanın araştırma grubunu Ankara'da yer alan bir vaklf üniversitesinde 2018-2019 bahar döneminde ögrenim gören 272 eğitim fakültesi ögrencisi oluşturmaktadır. Verilerin toplanma sürecinde ögrencilere "akıllı telefon benim için ..... gibidir çünkü ......" cümlesi verilmiş ve

$\underline{\text { Anahtar Kelimeler }}$

Akıllı telefon

kullanimi,

metafor,

üniversite ögrencileri tamamlamaları istenmiştir. Akıllı telefonlar ile ilgili 208 metafor oluşturulmuş ve metaforlar 9 tema altında toplanmıştır. Temalar, vazgeçilmez ve zorunlu bir araç olarak telefon, kolaylaştırıcı ve işlevsel bir araç olarak telefon, bağımlılık yaratan bir araç olarak telefon, eğlence kaynağı olarak telefon, sosyal destek aracı olarak telefon, bilgi edinme aracı olarak telefon, iletişim ve erişim aracı olarak telefon, dengeli kullanılması gereken bir araç olarak telefon ve vazgeçilebilir bir araç olarak telefon olarak isimlendirilmiştir. Üretilen metaforlar değerlendirildiğinde, katılımcıların akıllı telefonları hayatlarının vazgeçilmez ve kolaylaştırıcı bir parçası olarak gördükleri ve çoğunlukla telefonların olumlu etki ve özelliklerini belirttikleri görülmektedir.

\section{Abstract}

The purpose of this study is to explore the metaphoric perceptions of education faculty students towards smartphones. In this qualitative study, metaphors are used and the data analyzed by content analysis. The research group of the study consists of 272 education faculty students from a Foundation University in Ankara in the spring semester of 2018-2019. Participants were asked to complete sentences as 'Smartphone is like ... because.... According to the results, participants used 208 metaphors about smartphones in 9 conceptual categories. The categories which produced metaphors most about the university students were named as follows; Telephone as an indispensable and compulsory tool, telephone as a facilitating and functional tool, telephone as an addictive tool, telephone as a source of entertainment, telephone as a mean of social support, telephone as a mean of information, telephone as a mean of communication and access, telephone should be used in a balanced way as a tool and telephone as a dispensable tool. Considering the metaphors produced in the study, the smartphones are indispensable and facilitating for the participants and they mostly indicate the positive effects and features of the phones.

Using smartphones, metaphor, university students

Çetin-Gündüz, H., Kızıl-Aslan, Z., \& Güçlü, C.H. (2021). Eğitim fakültesi öğrencilerinin akıllı telefonlara yönelik algıları: metafor analizi ile bir değerlendirme. Muğla Sıtkı Koçman

Atıf için:

For Citation Üniversitesi Eğitim Fakültesi [MSKU Journal of Education], 8(1), 102-116. DOI: 10.21666/muefd.765165

Received: 06.07.2020

Accepted: 09.03.2021

Published: 01.05.2021

\footnotetext{
${ }^{1}$ Başkent Üniversitesi, Eğitim Bilimleri, RPD, hicrancetin@gmail.com ORCID: 0000-0002-5899-9772

${ }^{2}$ Başkent Üniversitesi, Eğitim Bilimleri, RPD, zkizil@baskent.edu.tr ORCID:0000-0003-2213-1178

${ }^{3}$ Başkent Üniversitesi, Eğitim Bilimleri, RPD, chozdemir@baskent.edu.tr ORCID:0000-0002-8262-2676
} 
Bilim ve teknolojideki gelişmeler kablosuz internet erişiminin ve taşınabilir cihazların yaygınlaşmasına olanak sağlamıştır. Bu cihazlar arasında yer alan akıllı telefon terimi, kablosuz bağlantı özellikli işlevlere, uygulamalara ve internete esnek erişime sahip cep telefonları anlamına gelmektedir (Yang, Asbury ve Griffiths, 2018). Modern hayatta akıllı telefonlar, kullanıcıya sunduğu geniş uygulama seçenekleri ve mobil etkileşim firsatlarıyla bireylerin yaşamlarında vazgeçilmez araçlar olmuşlardır. Özellikle internetin yaygın kullanımı gün geçtikçe artmaktadır. Akıllı telefonların küresel pazara nüfuz etme oranı, bir diğer deyişle interneti kullanan nüfusun genel nüfusa oranı (internet penetrasyonu) 2011'de \%10 iken 2018'de \%36'ya çıkarak çarpıcı bir artış göstermiş̧ir (Statista, 2018).

Dünya genelinde akı1lı telefon kullanıcı sayısı 2016 yılında 2,5 milyar kişi iken, bu rakamın 2021 yılında 3,8 milyar kişiye ulaşması beklenmektedir (Statista, 2019). Türkiye'de Hanehalkı Bilişim Teknolojileri Kullanım Araştırması sonuçlarına göre (TÜİK, 2019), 2004 yılında \%53,7 olan akıllı telefon kullanım oran1 2019 yılında \%98,7'ye ulaşmıştır. 13 ülkede belirli bir amaç doğrultusunda oluşan küresel bir ekip olarak We Are Social ve Hootsuit her yıl dünyaya ve Türkiye'ye ilişkin internet ve sosyal medya kullanım bilgilerine erişmemizi sağlayan istatistikler sunmaktadır. 2018 yılı raporuna göre Türkiye nüfusunun \%73'ü mobil teknoloji kullanıcısıdır (Hootsuite, 2018). 2019 istatistiklerine göre ise, 82,4 milyon nüfusu olan Türkiye'de nüfusun \%93'ü mobil kullanıc1, \%72'si İnternet kullanıcısı, \%63'ü aktif sosyal medya kullanıcısı ve \%53'ü aktif mobil sosyal medya kullanıcısıdır. Yetişkin insanların \%98'i cep telefonu kullanırken, bunların \%77'si ak1llı telefon kullanmakta ve günde ortalama 7 saatlerini internette geçirmektedirler. Sosyal medya kullanıcılarının yaş aralıklarına bakıldığında ise 18-24 (\%24) ve 25-34 (\%33) yaş gruplarının, dağılımın yarısından fazlasını oluşturduğu görülmektedir (We Are Social, 2019). 2020 yılındaki raporda ise mobil internet kullanımında Türkiye'nin dünya ortalamasının üzerinde zaman harcadığı ifade edilmektedir (We Are Social, 2020). Yoğun internet kullanımı ise beraberinde pek çok sosyal, psikolojik ve akademik sonucu beraberinde getirmektedir.

Teknoloji ile olan etkileşimlerimizin farklı ve pek çok sayıda psikolojik sonucu nasıl etkilediği yapılan çalışmalarca incelenmektedir (Shaw, Ellis ve Ziegler, 2018). Akıllı telefonlar sağladıkları kolaylıkların yanında bilinçsiz ve aşırı kullanıldığında stres (Hawi ve Samaha, 2016), narsizm (Ksinan, Mališ ve Vassonyi, 2019), düşük özsaygı (Kuss ve Griffiths, 2011), kompülsif davranışlar (Lin ve diğerleri, 2014) ve kayg1 (Richardson, Hussain ve Griffiths, 2018) gibi ruh sağlığı sorunlarına ve düşük akademik performansa (Hawi ve Samaha, 2016; Kibona ve Mgaya, 2015; Lepp, Barkley ve Karpinski, 2015; Mendoza, Pody, Lee, Kim ve McDonough, 2018) neden olabilmektedir. Akıllı telefon kullanımının riskleri, yan etkileri ve çeşitli değişkenlerle ilişkilerini konu alan 22 çalışmayı gözden geçiren Spitzer (2015), uyku bozuklukları, yalnızlık, bağımlılık, depresyon, kayg1, artan alkol ve tütün tüketimi, dikkat eksikliği, kişilik bozuklukları, saldırganlık ve hoşnutsuzluk gibi durum ve değişkenlerle akıllı telefon kullanımı arasında ilişki bulunduğunu belirtmektedir.

Alanyazında akıllı telefonların kullanımına yönelik farklı yaş gruplarında gerçekleştirilen çalışmalar yer almaktadır (Horwood ve Anglim, 2019; Kwon, Yoon, Noh, Chun ve Han, 2017; Lee, Chang, Lin ve Cheng, 2014; Mascheroni ve Ólafsson, 2016; Sohn, Rees, Wildridge, Kalk ve Carter, 2019). Ergenlik dönemindeki bireylerin akıllı telefon kullanımlarına yönelik çeşitli sayıda araştırma olduğu gibi (Lee ve Lee, 2017; Lemola, Perkinson-Gloor, Brand, Dewald-Kaufmann ve Grob, 2015; Kwon, Kim, Cho ve Yang, 2013; Škařupová, Ólafsson ve Blinka, 2016) genç yetişkinlerin akıllı telefon kullanımına odaklanan pek çok araştırma da yapıldığı görülmektedir (Csibi, Griffiths, Demetrovics ve Szabo, 2019). De-Sola Talledo, de Fonseca ve Rubio (2017) problemli akıllı telefon kullanımını 16-65 yaş arası bireylerde incelemiş ve uyguladıkları problemli mobil telefon ölçeğine dayanarak özellikle 16-25 yaş aralığındaki bireylerin risk taşıdığı belirtmişlerdir. Bu nedenle çalışmalar genellikle üniversite öğrencileri örnekleminde yoğunlaşmaktadır.

Akıllı telefon kullanımı ile ilgili üniversite öğrencileriyle yapılan araştırmalar dikkat çekici sonuçlar sunmaktadır. 785 üniversite öğrencisi ile yürütülen bir çalışmada öğrencilerin \%91,7'sinin akıllı telefona sahip olduğu ve bu öğrencilerin \%40,1'inin günlük akıllı telefon kullanım sürelerinin ortalama 4-6 saat olduğu tespit edilmiştir (Kahyaoğlu-Süt, Kurt, Uzal ve Özdilek, 2016). Benzer bir çalışmada (James ve Drennan, 2005) üniversite öğrencilerinin günlük akıllı telefon kullanım sürelerinin 1,5 ile 5 saat arasında değiştiği görülmektedir. Bu oranın özel günler, etkinlikler, yalnız ve üzgün hissedilen zamanlarda arttığı saptanmıştır. Gezgin, Hamutoğlu, Samur ve Yıldırım'ın (2018) çalışmalarında, akademik başarı düzeyi düşük olan öğrencilerin, başarı düzeyi daha yüksek olan öğrencilere göre akı1lı telefon bağımlılık riskinin yüksek olduğunu bildirilmiştir. Ek olarak, üniversite öğrencilerinin akı1lı 
telefonlarını video izlemek, sosyal ağ sitelerinde zaman geçirmek, arama yapmak, mesajlaşmak, müzik dinlemek ve internet üzerinden iletişime geçmek amacıyla kullandıkları belirtilmektedir.

Aday sınıf öğretmenlerinde problemli akıllı telefon kullanımını inceleyen Altundağ ve Bulut (2017) çalışmaları sonucunda kadın öğrenciler, bilinçli kullanım yapamayan ve eğitimi ihtiyacı olmadığını ifade eden öğrencilerin problemli akı1lı telefon kullanım düzeylerinin yüksek olduğu bildirilmiştir. Aynı çalışmada, akıllı telefon, internet ve sosyal medya kullanım süreleri uzadıkça problemli akıllı telefon kullanım düzeyinin de arttığı belirtilmiştir. Problemli akıllı telefon kullanımıyla birlikte nomofobi (mobil telefon yoksunluğu korkusu) kavramı alanyazına girmiştir. Üniversite öğrencilerinde nomofobinin araştırıldığı bir çalışmada (Erdem, Türen ve Kalkın, 2017), katılımcıların \%54'ünün nomofobik olduğu, nomofobinin kadınlarda daha yüksek olduğu, yaş arttıkça nomofobi düzeyinin azaldığı ve günlük akıllı telefon kullanma süresi arttıkça nomofobi düzeyinin arttığ1 tespit edilmiştir. Akıllı telefon kullanım süresi ile nomofobi arasındaki ilişkiyi işaret eden farklı çalışmalara (Gezgin, Şumuer, Arslan ve Yıldırım, 2017; Sırakaya, 2018) ek olarak akıllı telefon ve kişilik gibi psikososyal gelişim alanlarını ele alan çalışmalar da (Öz ve Tortop, 2018) bulunmaktadır. Alanyazın taraması sonucunda, akıllı telefon kullanım süresi ve amaçları, nomofobi ve cinsiyet ilişkisi değişkenlerinin sıklıkla ele alındığı görülmektedir.

Alanyazın incelendiğinde teknoloji, internet ve taşınabilir cihazlarla ilgili metafor çalışmalarının da çoğalmaya başladığı görülmektedir. Örneğin Karaçam ve Aydın (2014) 163 ortaokul öğrencisinden "Teknoloji” kavramına yönelik 68 farklı metaforlar tespit etmişlerdir. Katılımcıların en fazla ürettiği metaforlar su, insan, uçak, güneş, 1şık, ay, lamba, bilgisayar, makine, saat ve robot şeklinde sıralanmıştır. Ek olarak öğrencilerin teknoloji kavramına ilişkin algılarının çoğunlukla olumlu yönde olduğu tespit edilmiştir. Şahin ve Baturay'ın (2013) ise 251 lise öğrencisi ile yapmış oldukları çalışmada, "Internet" kavramına yönelik 92 farklı metafor ortaya çıkmıştır. En çok ifade edilen metaforlar su, hayat, yaşam, kitap, bilgi deposu, kütüphane, ansiklopedi, arkadaş, yardımcı, şeytan, sigara ve alkol olmuştur.

Ekici’nin (2016) öğretmen adaylarının bilgisayar kavramına yönelik kullandıkları metaforları belirlediği çalışmasında 123 farklı metafor saptanmıştır. En çok ifade edilen metaforlar beyin, televizyon, kitap, sigara, ansiklopedi, kütüphane, evrensel bilgi kutusu, arkadaş, cep telefonu ve dünya olmuştur. Benzer bir çalışmada (Güneyli ve Özkul, 2013) bilgisayar kavramına yönelik 81 katılımcıdan 47 farklı metafor tespit edilmiş ve en çok ifade edilen metaforlar beyin ve insan olmuştur. Saraç (2019), İstanbul ilinde bir ortaokulda toplam 166 ortaokul 8. sınıf öğrencisinden cep telefonu kavramına ait 50 farklı metafordan en fazla dost, oyuncak, organ, insan, araba, saat, su, kitap, hayat, kurtarıc1 metaforları tespit edilmiş ve bu metaforlar en çok kullanım amacına göre değişen bir araç ile yaşam için vazgeçilmez bir araç kategorileri altında toplanmıştır. Benzer bir çalışmada (Şenel, 2016), "Cep telefonu” kavramına yönelik 123 katılımcıdan 69 farklı metafor tespit edilmiştir. Çalışmanın sonucunda üniversite öğrencilerinin çoğunluğunun cep telefonuna yönelik algıları olumluyken, bazı öğrencilerin cep telefonunu tehlikeli bir unsur ve bağımlılığın kaynağı olarak belirttikleri görülmüştür. Polat'ın (2018) üniversite öğrencilerinin akıllı telefona yönelik metaforik algılarını incelediği çalışmasında ise, katılımciların kullandıklarını metaforlar niyet (olumlu tutum \%81- olumsuz tutum \%19), algilanan kullanım kolaylığı (\%16), algılanan fayda (\%17), akıllı telefon bağımlılığı $(\% 48,3)$ ve bilinçli kullanım $(\% 10,8)$ kategorileri olmak üzere birbiriyle ilişkili beş farklı temada birleşmiştir.

Yapılan çalışmalar incelendiğinde, özellikle gençlerin akıllı telefon kullanımlarının farklı değişkenlerle ele alındığı görülmektedir. Akıllı telefonların yoğun kullanımının gençlerin akademik yaşantılarında olumsuz sonuçlarla karşılaşmalarında bir etmen olabildiği öne sürülmektedir (Spitzer, 2015). Ayrıca yoğun akıllı telefon kullanımının gençlerin ruh sağlığına olumsuz etkileri olduğunu bildiren çalışmalar bulunmaktadır (Csibi ve diğerleri, 2019; Dixit ve diğerleri, 2010; King ve diğerleri, 2014). Akı1lı telefonların, kullanımının yoğunluğu ve sıklığına bağlı olarak gençler üzerinde pek çok etkisi olduğu yapılan çalışmalar tarafından ortaya konulmuştur. Bu etkiden hareketle, üniversite öğrencilerinin akıllı telefonlarını kullanım amaç ve sıklıklarına ilişkin bilgi edinmenin, akıllı telefonların gençlerin yaşamındaki önemi hakkında bilgi sağlayacağı düşünülmektedir.

Sonuç olarak, üniversite dönemindeki bireylerin hem içinde bulundukları gelişim dönemi hem de dijital dünya ile olan yakınlıkları ve etkileşimleri dikkate alındığında akıllı telefonlara yönelik algılarının belirlenmesi önemli hale gelmektedir. Yerli alanyazın incelendiğinde özellikle eğitim fakültelerinde okuyan öğrencilerin akıllı telefonlara ilişkin algılarına yönelik sınırlı sayıda araştırma göze çarpmaktadır. Bu araştırmalarda benzer şekilde eğitim fakültesi öğrencilerinin akıllı telefonlara yönelik metaforik algıları ele alınmakla birlikte, özellikle gelecek nesillerin eğitiminden sorumlu olacak olan 
öğretmen adaylarının hayatlarında akıllı telefonların anlamını öğrenebilmek için daha fazla çalışmaya ihtiyaç duyulduğu düşünülmektedir. Akıllı telefonlara bağımlı bir yaşam ve aşırı kullanımlar bireyleri sadece fiziksel olarak değil psikolojik olarak da etkilemektedir. Bu etkininin öğretmen adaylarındaki görünümü sadece bireysel sonuçlar değil yeni nesillerin üzerindeki sonuçları ile de anılacaktır. $\mathrm{Bu}$ nedenle yapılacak çalışmalar aracılığı ile eğitim fakültesindeki öğrencilerin algılarına dayalı olarak olumlu ya da olumsuz anlamlar daha derinlemesine incelenebilir ve olası olumsuz etkilere yönelik planlanacak çalışmalarda verilerden yararlanılabilir. Farklı fakültelerdeki öğrencilerin akıllı telefon algılarına ilişkin yapılan çalışmalar daha bütüncül değerlendirmelerin yapılmasında da önemli olacaktır. Ayrıca bu çalışma ile eğitim fakültesindeki öğrencilerin hayatında akıllı telefonun anlamı tanımlanarak literatürdeki diğer bulgularla tutarlılığın ya da farklılıkları ortaya konulabileceği ve daha aydınlatıcı ve karşılaştırmaya dayalı değerlendirmelerin yapılabileceği düşünülmektedir. Bu kapsamda çalışmada eğitim fakültesi öğrencilerinin akıllı telefonlara yönelik algılarına ilişkin bilgi sağlanacak ve geleceğin öğretmenlerinin akıllı telefon kullanım alışkanlıklarına dair yönelimlerini incelenecektir. Çalışma sonucunda elde edilen bilgiler, özellikle yöneticilerin ve eğitimcilerin, öğrencilerin akıllı telefonlarıyla ilişkini ve yönelimlerini anlaması ve hatta bu yönelimi kullanması açısından önemlidir. Bu araştırmanın genel amacı Ankara İlinde bir vakıf üniversitesinin Eğitim Fakültesinde öğrenim gören öğrencilerin akıllı telefonlara yönelik algılarının metaforlar yoluyla belirlenmesidir. Bu genel amaç doğrultusunda aşağıdaki sorulara cevap aranmıştır:

1. Eğitim fakültesi öğrencilerinin akıllı telefona ilişkin ürettikleri metaforlar nelerdir?

2. Eğitim fakültesi öğrencilerinin akıllı telefonlara yönelik metaforik algıları kavramsal olarak hangi temalar altında toplanmaktadır?

\section{Yöntem}

\section{Araştırmanın Modeli}

$\mathrm{Bu}$ araştırmada katılımcıların akıllı telefonlara ilişkin görüşlerini belirlemek amacıyla metaforlardan yararlanılarak nitel bir çalışma yürütülmüştür. Araştırmada nitel araştırma desenlerinden olgu bilim deseni kullanılmıştır. Olgubilim (fenemonoloji), belirli bir olgunun altında yatan ortak anlamları keşfetmeyi amaçlar ve olayların ortaya çıkışı ve özlerini keşfetme amacı taşımaktadır (Baker, Wuest ve Stern, 1992). Bir diğer deyişle olgubilim deseni farkında olduğumuz ancak derin ve detaylı bir anlayışa sahip olmadığımız olgulara odaklanmaktadır (Yıldırım ve Şimşek, 2013). Araştırmacı olgunun kavramlar ve temalar çerçevesinde tanımlanması için çalışır (Onat Kocabıyık, 2015). Araştırmada metaforların tercih edilmesinin nedeni akıllı telefonların öğretmen adaylarının öznel dünyalarındaki karşılığını mecazlar yoluyla betimlenebilmesidir (Yıldırım ve Şimşek, 2013).

\section{Çalışma Grubu}

Çalışma grubunu Ankara'da yer alan bir vakıf üniversitesinin eğitim fakültesinde 2018-2019 bahar döneminde öğrenim gören 208 üniversite öğrencisi oluşturmaktadır. Araştırmaya katılan öğrencilerin tamamı akı1lı telefona sahiptir. Katılımcıların 175'i $(\% 84,1)$ kadın, 33'ü $(\% 15,9)$ erkeklerden oluşmaktadır. Araştırmaya katılan öğrencilerin sınıf düzeyleri 1.sınıf $(\% 47,1)$ ile 4. sınıflardır $(\% 52,9)$. Katılımcıların yaşları 18-33 arasında değişmekte ve PDR (\%33,2), Türkçe Öğretmenliği (\%22,6), Sınıf Öğretmenliği $(\% 16,3)$, İngilizce Öğretmenliği $(\% 11,5)$, Okul Öncesi Öğretmenliği $(\% 11,5)$ ve Matematik Öğretmenliği $(\% 4,8)$ öğrencilerinden oluşmaktadır. Başlangıçta 272 katılımcının verdikleri cevaplar incelenmiş, metafor niteliğinde olmayan ya da boş bırakılan 64 form çıarıllmış ve 208 form değerlendirmeye alınmıştır.

\section{Verilerin Toplanması}

Araştırma verilerinin toplanmasında öğrencilerin kolay erişilebilir olması amacıyla uygun örnekleme (convenience sampling) yöntemi kullanılmıştır (Yıldırım ve Şimşek, 2013). Araştırma verileri üniversite öğrencilerinin gönüllü katılımı ile toplanmış, bilgilerin bilimsel amaç dışında kullanılmayacağı ve istenilirse araştırmadan ayrılabilecekleri iletilmiştir. Öğrencilere formları doldurmadan önce araştırmanın amacı açıklanmış ve formu doldurmaları için yaklaşık 20 dakikalık bir süre verilmiştir. Öğrencilerden "Akıllı telefon benim için ..... gibidir çünkü ......" cümlesini tamamlamaları istenmiştir. Metafor cümlesinin dışında demografik bilgilerin yer aldığ 1 bir form da verilerek yaş, cinsiyet, sınıf, bölüm gibi konularda katılımcılara ilişkin bilgiler toplanmıştır. Çalışmada veri toplama ve yazım 
sürecinde bilimsel ve etik kurallara uyulmuş, toplanan veriler üzerinde herhangi bir tahrifat yapılmamışıtır.

\section{Verilerin Analizi}

Verilerin analizinde toplanan verileri açıklayabilmek, kavramları ve ilişkileri ortaya koyabilmek amacıyla (Yıldırım ve Şimşek, 2013) içerik analizi yöntemi kullanılmıştır. Araştırmacılar öncelikle her bir maddeyi inceleyerek metafor cümlesi olarak uygunluğunu değerlendirmiş, uygun bulunmayan ifadeler değerlendirmeye alınmamıştır. Metafor cümlesi olarak uygun bulunmayan ifadelerin bir grubu eksik bırakılmış metaforlardan oluşmaktadır. Örneğin akıllı telefon benim için boş vakit uğraşı gibidir çünkü ... ifadesinde bir metafor kullanılmakla birlikte metaforun mantıksal dayanağı açıklanmamış çünkü ifadesinden sonra boş bırakılmıştır.

Metafor cümlelerinin bir grubunda ise açıklanan mantıksal dayanağın (çünkü... ile başlayan açıklama cümleleri) metaforu açıklama gücüne ve metafor ile ilişkisine bakılmıştır. Mantıksal dayanağı metafor olarak uygun bulunmayan maddeler değerlendirme dışında bırakılmıştır. Örneğin "Akı1lı telefon benim için eski sevgili gibidir çünkü neler olduğunu merak ediyorum ama o biraz akılsız" ifadesini kullanan ögrencinin akıllı telefonu sevgiliye benzetirken mantıksal dayanağı sevgili kavramıyla yeterince ilişkilendiremediği ve açıklayamadığı görülmüştür. Benzer şekilde "Akıllı telefon benim için önemli gibidir çünkü her istediğimi rahatlıkla halledebiliyorum", "Akı1lı telefon benim için önemli bir şey gibidir. Çünkü değil.” ifadelerinde de metaforların mantıksal dayanakları açıklayıcı şekilde sunulmamıştır. Ayrıca bu cümlelerde de metafor olarak tanımlanan "önemli bir şey gibidir" ifadeleri de yeterince açı değildir.

"Akı1lı telefon benim için teknoloji gibidir. Çünkü teknoloji işlerimizi kolaylaştırmak için vardır. Telefonda benim işimi kolaylaştırıyor." ifadesinde ise metafor olarak teknoloji kullanılmakla birlikte akıllı telefon bir teknolojik araç olduğu için mecaz içermediği düşünülerek metafor olarak kabul edilmemiştir.

Değerlendirmeye alınmayan metafor cümleleri elendikten sonra geriye kalan ifadeler araştırmacılar tarafından tekrar değerlendirilerek formlar numaralandırılarak kodlanmıştır. Kadınlar için "K" ve erkek katılımcılar için "E" harfinin yanında sıra numarası kullanılmıştır. Metaforlara ilişkin kod ve temaların belirlenmesi aşaması üç araştırmacı tarafından ayrı ayrı gerçekleştirilmiştir. Bu aşamada verilerin analizinde verilerin kodlanması, temaların bulunması, kodların ve temaların düzenlenmesi ve bulguların tanımlanarak yorumlanması aşamaları izlenmiştir (Yıldırım ve Şimşek, 2013).

Verilerin kodlanması aşamasında her ifade incelenmiş ve kavramsal olarak ne ifade ettiği bulunmaya çalışılmıştır. Kodlamada Stauss ve Corbin (1990) tarafından tanımlanan genel bir çerçeve ile kodlama yöntemi kullanılmıştır. Bu kodlama sürecinde genel kategoriler ya da temalar önceden belirlenmekte ve tümevarımcı bir yaklaşımla verilerin incelenmesi sonucu ortaya çıkan ayrıntılı kodlar da daha önceden oluşturulan yeni kodlara eklenmektedir (Yıldırım ve Şimşek, 2013). Daha sonra üç araştırmacının kodlamaları gözden geçirilerek uyumuna bakılmıştır. Farklı araştırmacılar tarafindan yapılan kodlamalarda benzerlik oranı güvenirlik hesaplanmasında kullanılmaktadır. Miles ve Huberman (1994) modelinde içsel tutarlılık olarak adlandırılan ve kodlayıcılar arasındaki görüş birliği olarak kavramsallaştırılan bu benzerlik: $\Delta=\mathrm{C} \div(\mathrm{C}+\partial) \times 100$ formülü kullanılarak hesaplanmaktadır. Formülde, $\Delta:$ Güvenirlik katsayısını, $C$ : Üzerinde görüş birliği sağlanan konu/terim sayısını, $\partial$ : Üzerinde görüş birliği bulunmayan konu/terim sayısını ifade etmektedir. İçsel tutarlılığı veren kodlama denetimine göre kodlayıcılar arası görüş birliğinin en az \% 80 olması beklenmektedir (Baltacı, 2017). Araştırmacıların görüş birliğinin olduğu metafor sayıs1 174, görüş birliği olmayan kategori sayısı 34'tür. Bu formüle göre araştırmacıların kategori eşleştirmelerinde güvenirlik \%84 olarak bulunmuştur.

Araştırmanın geçerliğini sağlamaya ilişkin bilgiler değerlendirildiğinde nitel çalışmalarda geçerliği elde etmeye yönelik zorluklar tanımlanmaktadır. Buna karşın geçerliğin değerlendirilmesinde sonuçların benzer gruplara ya da ortamlara aktarılabilirliği ve araştırma sonucuna ulaşılırken izlenen sürecinin çalışılan gerçekliği ortaya çıkarmadaki yeterliğine işaret edilmektedir (Yıldırım ve Şimşek, 2013). Bu kapsamda araştırmanın bilimsel bir yolu takip ederek gerçekleştirilmesi, analiz sürecinin ayrıntıları ile sunulması ve metaforlara ayrıntıları ile yer verilmesi, araştırma bulgularının kendi içinde anlamlı ve tutarlı olması, ortaya çıkan kavramların anlamlı bir bütün oluşturması gibi nedenlerle araştırmanın aktarılabilir olduğu düşünülmektedir. Araştırmada katılımcıların kodlanarak görüşlerinin doğrudan aktarılmasının da çalışılan gerçekliği ortaya çıkarmaya işaret ettiği düşünülmektedir. 


\section{Bulgular}

$\mathrm{Bu}$ bölümde araştırmaya katılan üniversite öğrencilerinin "Akıllı telefon" ile ilgili geliştirdikleri metaforlara ve oluşturulan temalara ilişkin bulgulara yer verilmiştir.

\section{Öğrencilerin “Akıllı Telefon” İle İlgili Ürettiği Metaforlar}

Öğrenciler tarafından akıllı telefonlara ilişkin 78 metafor oluşturulmuş ve metaforlar 9 tema altında toplanmıştır. Katılımcıların akıllı telefonları tanımlamak ilişkin kullandıkları metaforlar, kullanma sıklıkları ve yüzdelikleri Tablo 1'de verilmiştir.

Tablo 1

Öğrencilerin “Akıllı Telefon” İçin Ürettiği Metaforların Frekans ve Yüzde Dağıllımları

\begin{tabular}{|c|c|c|c|c|c|c|c|c|}
\hline Metafor & $\mathrm{f}$ & $\%$ & Metafor & $\mathrm{f}$ & $\%$ & Metafor & $\mathrm{f}$ & $\%$ \\
\hline 1.İhtiyaç & 2 & 10.1 & 26.BilgiKutusu/Kaynağı & 2 & 1.0 & 51.Sakız & 1 & 0.5 \\
\hline 2.Arkadaş & 1 & 8.2 & 27.İletişim Aracı & 2 & 1.0 & 52.Araç & 1 & 0.5 \\
\hline 3.Su & 1 & 6.7 & 28.Kalp pili & 1 & 0.5 & 53.Çay & 1 & 0.5 \\
\hline 4.El/ayak/kol Organ/uzuv & 1 & 6.7 & 29.Evlat/ Çocuk & 1 & 0.5 & 54.Levye & 1 & 0.5 \\
\hline 5.Araç & 1 & 5.8 & 30.Baba & 1 & 0.5 & 55.Gözlük & 1 & 0.5 \\
\hline 6. Hayat & 8 & 3.8 & 31.Cips & 1 & 0.5 & 56.Uçak bileti & 1 & 0.5 \\
\hline $\begin{array}{l}\text { 7.Eğlence aracı ve } \\
\text { Eğlence Programı }\end{array}$ & 7 & 3.4 & 32.Oyun konsolu & 1 & 0.5 & 57.Aşk & 1 & 0.5 \\
\hline 8.Asistan/ Yardımc1 & 7 & 3.4 & 33.İş & 1 & 0.5 & 58.Bal/kaymak & 1 & 0.5 \\
\hline 9.Alışkanlık & 6 & 2.9 & 34.Çanta & 1 & 0.5 & 59.İletişim kanalı & 1 & 0.5 \\
\hline 10.Yiyecek/yemek & 6 & 2.9 & 35.Kap1 & 1 & 0.5 & 60.İlaç & 1 & 0.5 \\
\hline 11.Ekmek ve su & 5 & 2.4 & 36.Hobi & 1 & 0.5 & 61.Ulaşım Aracı & 1 & 0.5 \\
\hline 12.Nefes almak & 4 & 1.9 & 37.Ansiklopedi & 1 & 0.5 & 62.Tatil & 1 & 0.5 \\
\hline 13.Oyuncak & 4 & 1.9 & 38.Puzzle & 1 & 0.5 & 63.Hayat Kolaylaştırıcı & 1 & 0.5 \\
\hline 14.Aile & 3 & 1.4 & 39.Saat & 1 & 0.5 & 64.Alet & 1 & 0.5 \\
\hline 15.Sigara & 3 & 1.4 & 40.Araba & 1 & 0.5 & 65.Mucize & 1 & 0.5 \\
\hline 16.Çikolata & 3 & 1.4 & 41.Meyve suyu & 1 & 0.5 & 66.Ayrılmaz bir parça & 1 & 0.5 \\
\hline 17.Mektup & 3 & 1.4 & 42.Gezme & 1 & 0.5 & 67.Düzen & 1 & 0.5 \\
\hline 18.Cüzdan & 3 & 1.4 & 43.Kitap & 1 & 0.5 & 68.Eş & 1 & 0.5 \\
\hline 19.Bağımlılık & 3 & 1.4 & 44.Duyu Organı & 1 & 0.5 & 69.Güvence & 1 & 0.5 \\
\hline 20. Vazgeçilmez & 3 & 1.4 & 45.Okyanus & 1 & 0.5 & 70.Beslenme & 1 & 0.5 \\
\hline 21.Dünya & 2 & 1.0 & 46.Gazete & 1 & 0.5 & 71.Bedenim & 1 & 0.5 \\
\hline 22.Eğlence & 2 & 1.0 & 47.Mağaza & 1 & 0.5 & 72.İp & 1 & 0.5 \\
\hline 23.Bilgisayar & 2 & 1.0 & 48.Bütünlük & 1 & 0.5 & 73.Kahve & 1 & 0.5 \\
\hline 24.Bilgi & 2 & 1.0 & 49.Kütüphane & 1 & 0.5 & 74.Televizyon & 1 & 0.5 \\
\hline 25.Haberleşme aracı & 2 & 1.0 & 50.Müzik & 1 & 0.5 & 75. Hava & 1 & 0.5 \\
\hline
\end{tabular}

Tablo 1 incelendiğinde öğrencilerin akıllı telefona yönelik 75 farklı metafor olușturdukları görülmektedir. Öğrencilerin akıllı telefonlar için ilk beş sırada ihtiyaç (\%10,1), dost/arkadaş $(\% 8,2)$, su $(\% 6,7)$, el/kol/ayak/organ/uzuv $(\% 6,7)$, araç $(\% 5,8)$ metaforlarını kullandıkları görülmektedir.

\section{Anlamlarına Göre Metaforlar}

Akıllı telefonlara yönelik metaforlar anlamlarına göre olumlu, olumsuz ve hem olumlu hem olumsuz olarak değerlendirilmiştir. Katılımcılar en çok olumlu kategorisinde $(\mathrm{n}=175)$ metafor üretmişlerdir. Olumlu metaforlara ilişkin örnekler aşağ 1 da verilmiştir. 
sağllyor (E35).

“Akıllı telefon benim için çalışma alanı gibidir çünkü sosyal medyayı kazanç amaçlı kullanmamı

"Akıllı telefon benim için elim ayağım gibidir çünkü telefondan istediğim her şeye ulaşabiliyorum

(K60).

"Akıllı telefon benim için hayat gibidir. Çünkü hayatımın bir parçası oldu ve onsuz kendimi güvensiz hissediyorum (K89).,"

Katılımcıların akı1lı telefonlara yönelik ürettiği olumsuz metaforların (n=26) çoğunlukla bağımlılıkla ilişkilendirildiği görülmektedir. Katılımcıların "Akıllı telefon benim için sigara gibidir. Kullanmadığım zaman eksiklik hissedecek kadar bağımlıyım (K12), "Akıllı telefon benim için bağımlılık gibidir, çünkü ona alıştım, onsuz yapamıyorum (E182) ” ifadeleri olumsuz içeriklere örnek verilebilir. Bununla birlikte akıllı telefonların hem olumlu hem olumsuz yönüne işaret eden metaforların da $(\mathrm{n}=7)$ üretildiği görülmüştür. Bu metaforlara örnek olarak "Akıllı telefon benim için ekmek gibidir çünkü gereklidir ama fazlası zararlıdır (K2), "Akıllı telefon benim için levye gibidir. Çünkü amacına uygun kullanırsanız çok faydalı, bağımlılık boyutuna çıkarsa şakak kemiğinden girmişs bir levye gibi olur (K19)” ifadeleri verilebilir.

\section{Kavramsal Olarak Temalar}

Katılımcıların akıllı telefonlara yönelik oluşturdukları metaforlar içerik analizi sonucunda belirlenen 9 tema altında toplanmıştır. Bu temalara ilişkin frekans ve yüzdelik dağılımları Tablo 2'de gösterilmektedir.

Tablo 2

Akıllı Telefonlar İle İlgili Oluşturulan Metaforlara İlişkin Kavramsal Kategorilerin Frekans ve Yüzdelik Dağllımları

Kavramsal Temalar
Vazgeçilmez ve zorunlu bir araç olarak telefon

Kolaylaştırıcı ve işlevsel bir araç olarak telefon

A

He

Metaforlar

Hava, ekmek, su, ihtiyaç, kalp pili, el, elim-

kolum, hayat, yemek, çanta, vazgeçilmez, nefes almak, cüzdan, el-ayak, organ, gezme, yeme içme, organ, kol, uzuv, aşk, bal kaymak, hayatın akışı, sağ kol, alışkanlık, ayrılmaz bir parça, gereksinim, beden,

Asistan, vazgeçilmez, arkadaş, baba, iş, araç, puzzle, saat, araba, yardımcı, bilgisayar, mağaza, dünya, bütünlük, ihtiyaç, çay, gözlük, uçak bileti, iletişim kanalı, hayatın bir parçası, hayat kolaylaştırıcı, bilgi kutusu, alet, alışkanlık, düzen, dost, güvence,

Bağımlılık yaratan bir araç olarak telefon

Cips, sigara, evlat/osk

\begin{tabular}{ll|l|l}
$\begin{array}{l}\text { Cips, sigara, evlat/çocuk, ihtiyaç, aile, } \\
\text { alışkanlık, su, duyu organı, ekmek, kahve, }\end{array}$ & & 12,5 \\
\end{tabular}

sakız, hayat, bağımlılık, bitter çikolata, eş,

Eğlence kaynağı olarak telefon

\begin{tabular}{ll|l|l}
\hline $\begin{array}{l}\text { Eğlence aracı, oyuncak, çikolata, oyun } \\
\text { konsolu, hobi, müzik, televizyon, eğlence }\end{array}$ & 23 & 11,1 \\
& &
\end{tabular}
programı, araç, tatil, eğlence, sevdiğim yiyecek gibi,

\begin{tabular}{l}
\hline Sosyal destek aracı olarak telefon \\
\hline Bilgi edinme aracı olarak telefon
\end{tabular}

A

\begin{tabular}{l|l|l}
\hline Arkadaş, aile, dost, ip, & 16 & 7,7 \\
\hline Bilgi, dünya, kapı, ihtiyaç, ansiklopedi, araç, & 15 & 7,2
\end{tabular}

İletişim ve erişim aracı olarak telefon

kitap, okyanus, gazete, kütüphane, mucize, bilgi kaynağı, bilgisayar,

\begin{tabular}{l|l|l|l} 
& $\begin{array}{l}\text { aracı, ulaşım aracı, iletişim aracı, iletişim } \\
\text { aracı, }\end{array}$ & 12 & 5,8 \\
\hline $\begin{array}{l}\text { Dengeli kullanılması gereken bir araç olarak } \\
\text { telefon }\end{array}$ & İhtiyaç, levye, ilaç, araç, oyuncak, ekmek & 7 & 3,4 \\
\hline Vazgeçilebilir bir araç olarak telefon & Meyve suyu & 1 & 0,5 \\
\hline
\end{tabular}


Tablo 2 incelendiğinde akıllı telefonlara ilişkin metaforlardan üretilen temaların, vazgeçilmez ve zorunlu bir araç olarak telefon, kolaylaştırıcı ve işlevsel bir araç olarak telefon, bağımlılık yaratan bir araç olarak telefon, eğlence kaynağı olarak telefon, sosyal destek aracı olarak telefon, bilgi edinme aracı olarak telefon, iletişim ve erişim aracı olarak telefon, dengeli kullanılması gereken bir araç olarak telefon ve vazgeçilebilir bir araç olarak telefon başlıkları altında toplandığı görülmektedir.

"Vazgeçilmez ve zorunlu bir araç olarak telefon" temasında yer alan metaforların en çok üretilen metaforlar olduğu görülmektedir $(\% 29,8)$. Bu metaforların bir yandan yaşamsal olan hava, su, ekmek, gibi temel ihtiyaçlar ile açıklandığı ve zorunluluğunun vurgulandığı görülürken, bir yandan da çanta, ayrılmaz bir parça, ihtiyaç, gereksinim, alışkanlık gibi kavramlarla vazgeçilmez oluşuna işaret edildiği görülmektedir. Aynı zamanda kalp pili, nefes almak gibi yaşamsal kavramlarla ilişkilendirmenin yanında bedenin el, kol, uzuv, organ gibi bir parçası olarak da tanımlanmıştır. Vazgeçilmez ve zorunlu bir araç olarak telefon temasına ilişkin örnekler aşağıda verilmiştir.

Akall telefon benim için hava gibidir çünkü benim için hava kadar gerekli (K1).

Aklll telefon benim için kalp pili gibidir. Çünkü o olmadan yaşayamam (E17).

Akillı telefon benim için hayat gibidir. Çünkü hayatımın hemen her alaninda gerekli oluyor (K22).

Akillı telefon benim için çanta gibidir. Çünkü sürekli yanımda olması gerekir (K40).

Akıllı telefon benim için vazgeçilmez gibidir çünkü video, film, telefon oyunların seviyorum ve bunun için de akıllı telefona ihtiyaç duyuyorum. Aynı zamanda mesaj alma ve gönderme işleri içinde akıllı telefondan yararlaniyorum. (K47).

Akillı telefon benim için kolum gibidir. Çünkü kullanamadı̆̆ımda kendimi eksik hissediyor (K116).

Katılımcıların görüşlerine dayalı olarak ortaya çıkan bir diğer tema ise akıllı telefonların kolaylaştırıcı ve işlevsel olma yönüne işaret etmektedir. Bu tema altında toplanan metaforların telefonun hayatı kolaylaştırıcı rolüne ve olumlu özelliklerine işaret ettiği görülmektedir. Kolaylaştırıcı ve işlevsel bir araç olarak telefon temasına ilişkin örnekler aşağıda verilmiştir.

Akıllı telefon benim için asistan gibidir çünkü içinde ders notlarım, slaytlarım ve hatırlatıcılarım var (K9). Akıllı telefon benim için vazgeçilmez gibidir çünkü ailemden uzakta yaşıyorum. Banka işleri, faturalar, alışveriş, çoğu işimi buradan hallediyorum (K11).

Akıllı telefon benim için puzzle gibidir. Çok farklı alanlarda kullanabiliyorum (K63).

Akıll telefon benim için yardımcım gibidir çünkü ihtiyacım olan çoğu şeyi bulmama yardım eder (E70).

Akıllı telefon benim için mă̆aza gibidir çünkü alışverişimi hep oradan yapıyorum (K97).

Akıllı telefon benim için bir dost gibidir, çünkü hep yanımda ve sürekli kullanıyorum (K191).

Telefonun bağımlılık yaratan rolüne işaret eden metaforlar incelendiğinde ise sigara, cips, ekmek, kahve, sakız gibi kavramların kullanıldığı belirlenmiştir. Kullanılan kavramların ihtiyaç ve vazgeçilmezliğe ilişkin ifadelerden ziyade bağımlılığa işaret eden ifadeler olduğu görülmektedir. Bağımlılık yaratan bir araç olarak telefon temasına ilişkin örnekler aşağıda verilmiştir.

Akıllı telefon benim için sigara bă̆ımlılı̆̆ı gibidir çünkü içmek istemeseniz de parmaklarınız arar (K8).

Akıllı telefon bağımlılık gibidir çünkü telefonsuz kalmak benim için korkunç bir şey (K208).

Akallı telefon benim için nescafe gibidir çünkü her gün mutlaka kullanmam gerekir (K111).

Akıllı telefon benim için sakız gibidir çünkü elime aldığım zaman mutlaka ilgilenirim. Sakızı da aldı̆̆ımda çiğnemeden duramiyorum (K112).

Eğlence kaynağı olarak telefon teması altında toplanan metaforlar incelendiğinde oyun, eğlence programı, tatil gibi bir grup kavramın dolaylı yoldan, bir grup kavramın da televizyon, oyun konsolu, oyuncak, eğlence aracı gibi doğrudan eğlenceye işaret ettiği görülmektedir. Eğlence kaynağı olarak telefon temasına ilişkin örnekler aşağıda verilmiştir.

Aklll telefon benim için oyuncak gibidir oyun oynamak için kullaniyorum (E16). (Doğrudan)

Hobi gibidir. Slkıntıyl giderir. Farklı ve yeni şeyler görmemi sağlar (K52). (Dolaylı)

Akıllı telefonun sosyal destek rolü ise katılımcılar tarafından arkadaş, aile, dost ve ip metaforları ile ifade edilmiştir. Sosyal destek olarak telefon temasına ilişkin örnekler aşağıda verilmiştir.

Akıllı telefon benim için arkadaş gibidir çünkü yalnızlı̆̆ımı giderir (K104).

Akillı telefon benim için ailem gibidir çünkü her zaman yanımdadır (K82).

Akıllı telefonlara ilişkin sıcça vurgulanan özelliklerden birisi de bilgi edinme rolüne yöneliktir. $\mathrm{Bu}$ kapsamda oluşturulan metaforlar bilgi edinme aracı olarak telefon teması altında toplanmıştır. 
Oluşturulan metaforlar arasında kapı, ansiklopedi, araç, gazete, bilgi kaynağı yer almaktadır. Bilgi edinme aracı olarak telefon temasına ilişkin örnekler aşağıda verilmiştir.
Akullı telefon benim için bilgi gibidir çünkü merak ettiğim her ş̧eyi onunla saniyeler içinde öğrenebiliyorum (E36).
Aklll telefon benim için dünya gibidir çünkü olan bitenden haberdar oluyoruz (K48).
Akıllı telefon benim için ansiklopedi gibidir çünkü ihtiyacım olan bilgiler ulaşmamı sağlıyor (K23).
Aklll telefon benim için gazete gibidir çünkü genellikle son dakika haberlerine bakarım (E95).

Akıllı telefonların iletişim ve erişim aracı olarak kullanılmasına işaret eden temadaki metaforlar ise mektup, ulaşım aracı, iletişim aracı, haberleşme aracı telefonun ilk icadından bugüne olan en temel yönüne işaret etmektedir. İletişim ve erişim aracı olarak telefon temasına ilişkin örnekler aşağıda verilmiştir.

\title{
Akillı telefon benim için mektup gibidir çünkü insanlar ile asırlardır süren mektup geleneğini sürdürmüş̧ür (E27). \\ Akıllı telefon benim için ihtiyaç gibidir çünkü ailemden ve arkadaşlarımdan haber alabildiğim bir araçtır (K78).
}

Akıllı telefonun bu özelliklerinin yanında dengeli kullanımı ve vazgeçilebilir olmasına ilişkin üretilen metaforlar da bulunmaktadır. Dengeli kullanımda akıllı telefonun zararlı olabileceğine ilişkin görüşlerde belirtilerek eleştirel bir değerlendirme yapıldığı söylenebilir. Dengeli kullanılması gereken bir araç olarak telefon temasına ilişkin örnekler aşağıda verilmiştir.

\begin{abstract}
Akıllı telefon benim için levye gibidir. Çünkü amacına uygun kullanırsanız çok faydalı, bağımlılık boyutuna çılkarsa şakak kemiğinden girmiş bir levye gibi olur (K19).

Akıllı telefon benim için tıbbı ilaç gibidir çünkü dozunu bilmesek ya da ihtiyaç dışında kullanırsak bize zarar verir (K137).

Akıllı telefon benim için oyuncak gibidir, çünkü sürekli değil de bazı zamanlarda elime aldığım nesnedir (K194).
\end{abstract}

Vazgeçilebilir olma temasında ise "Akıllı telefon benim için meyve suyu gibidir çünkü onsuz da yaşayabilirim sadece su içmem yeterli olur (E22)" ifadesi yer almaktadır.

\section{Tartışma ve Sonuç}

Bu çalışmada yaşları 18-33 arasında değişen eğitim fakültesi öğrencilerinin akıllı telefonlara ilişkin algıları metafor analizi ile incelenmiştir. Öğretmen adayları tarafından akıllı telefonlara ilişkin oluşturulan 208 metafor, "Vazgeçilmez ve zorunlu bir araç olarak telefon $(\% 29,8)$ ", "Kolaylaştırıcı ve işlevsel bir araç olarak telefon (\%22,1)", "Bağımlılık yaratan bir araç olarak telefon (\%12,5)", "Eğlence kaynağı olarak telefon $(\% 11,1)$ ", "Sosyal destek aracı olarak telefon $(\% 7,7)$ ", "Bilgi edinme aracı olarak telefon $(\% 7,2)$ ", "İletişim ve erişim aracı olarak telefon $(\% 5,8)$ ", "Dengeli kullanılması gereken bir araç olarak telefon $(\% 3,4)$ " ve "Vazgeçilebilir bir araç olarak telefon $(\% 0,5)$ " olmak üzere 9 tema altında toplanmıştır. Öğrencilerin yoğun olarak akıllı telefonlarını vazgeçilmez ve zorunlu bir araç olarak gördükleri bulunmuştur. Öğrenciler akıllı telefonları hava, ekmek, su, ihtiyaç, el-kol gibi kavramlarla tanımlamış ve günlük kullanımlarında bir zorunluluk olarak belirtmişlerdir. Saraç (2018) ortaokul öğrencilerinin akıllı tahta ve cep telefonu hakkındaki görüşlerini incelediği araştırmasında benzer bir sonuca ulaşmış ve öğrencilerin cep telefonlarını vazgeçilemez bir araç (f=9) olarak gördüklerini ifade etmiştir. Yaşamı kolaylaştırmak için kullanılan bir aracın vazgeçilemez ve zorunlu görülmesi, akıllı telefonların öğrencilerin yaşamlarındaki yerini ve önemini destekler niteliktedir.

Akıllı telefonların yaşamı kolaylaştırıcı ve işlevsel olarak kullanımı öğrenciler arasında yaygın $(\% 22,1)$ bir algı olarak bulunmuştur. Öğrenciler akıllı telefonlarını yaşamlarının pek çok alanını düzenleme, planlama ve akademik amaçlarla kullandıklarını bildirmişlerdir. Üniversite öğrencileriyle yapılan bir metafor çalışmasında "İhtiyaçları gidermede kolaylaştırıcılık" en yaygın tema olarak bulunmuştur (Gezgin ve diğerleri, 2018). Akıllı telefonların kullanım kolaylığı ve çoğu kişi için kolay erişilebilir olması, hayatın pek çok alanında yaygın bir kullanım sağlamaktadır (Ling, 2003). Bu kullanımın akıllı telefonların öğrencilerin yaşamlarını kolaylaştırıcı bir araç olarak görmelerini sağladığı söylenebilir.

Bir diğer önemli sonuç ise, akıllı telefonların bağımlılık yaratan bir araç $(\% 12,5)$ olarak görülmesidir. Bu tema altında cips, sigara, alışkanlık ve kahve gibi benzetmeler yer almış ve öğrenciler akıllı telefonu bağımlılık yaratan bir araç olarak gördüklerini ifade etmişlerdir. Alanyazında akıllı telefon bağımlılığ 
kavramı pek çok araştırmada incelenmekte ve gün geçtikçe önemi artmaktadır. Nomofobi olarak tanımlanan mobil telefon yoksunluğu korkusunun üniversite öğrencileri arasında yaygın olduğunu gösteren çalışmalar bulunmaktadır (Erdem ve diğerleri, 2017; Adnan ve Gezgin, 2016; Yıldırım, Sumuer, Adnan ve Yıldırım, 2016; Tavolacci, Meyrignac, Richard, Dechelotte ve Ladner, 2015; SecurEnvoy, 2012). Öğrenciler arasında yaygınlı̆̆ giderek artan Nomofobi'nin akademik başarı, kaygı, stres gibi faktörlerle ilişki olduğu görülmektedir (Bragazzi ve Del Puente, 2014; Erdem, Türen ve Kalkın, 2016). Akıllı telefonların varlığının ve yoksunluğunun öğrencilerin yaşamlarında merkezi bir öneme sahip olduğu ve pek çok alanda etkili olduğu söylenebilir, ancak sigara, kahve ve cips gibi zararlı benzemelerin ifade edilmesi düşündürücüdür.

Eğlence aracı olarak telefon $(\% 11,1)$ teması içinde ise oyuncak, oyuncak konsolu, hobi ve tatil gibi benzetmeler yer almıştır. Üniversite öğrencileri ile yapılan çalışmalarda akıllı telefonların yaygın olarak internette gezinme, video seyretme ve oyun oynama gibi eğlence amaçlı kullanıldığı bulunmuştur (Lee ve diğerleri, 2014; Lepp, Barkley, Sanders, Rebold ve Gates, 2013; Wang, Wang, Gaskin ve Wang, 2015). Öğrencilerin sosyalleşme ve eğlence kaynağı olarak akıllı telefonlarına yöneldikleri ve akıllı telefonları aracılığı ile eğlence kaynaklarını biçimlendirdikleri söylenebilir.

Sürekli ve yoğun kullanımları sonucu akıllı telefonlar özellikle ergen ve genç yetişkinlerin sosyal yaşantılarının önemli bir parçası haline gelmiştir. Öğrencilerin akıllı telefonları sosyal destek aracı olarak algılamalarına ilişkin bulgular $(\% 7,7)$ bu durumu destekler niteliktedir. Grant ve O'Donohoe (2007) gençlerin akıllı telefonlarını "Ellerinin içindeki bir arkadaş olarak" gördüklerini belirtmiştir. Konan, Durmuş, Ağıroğlu Bakır ve Türkoğlu (2018) ise, üniversite öğrencilerinin algıladıkları sosyal destek ile akıllı telefon bağl11ıkları arasında olumsuz bir ilişki olduğunu bulmuşlardır. Akıllı telefonlarını arkadaş, aile ve dost gibi benzetmelerle tanımladıklarından dolayı öğrencilerin akıllı telefonlarına ilişkin duygusal bir yakınlık algıları olduğundan söz edilebilir.

Bilgi edinme aracı olarak telefon $(\% 7,2)$ temasında ise öğrenciler akıllı telefonlarını bilgi, dünya ve kapı gibi benzetmelerle tanımlamış ve genel olarak akıllı telefonların bilgiye erişimde sağladığı kolaylığa ilişkin algı ön plana çıkmıştır. Benzer şekilde Valk, Rashid ve Elder (2010) ve Tindell ve Bohlander (2012) akıllı telefonların öğrenciler tarafindan iletişim, bilgiye erişim ve öğrenme süreçlerinde kolaylaştırıcı bir olanak olarak görüldüğünü belirtmişlerdir.

İletişim ve erişim aracı olarak telefon $(\% 5,8)$ temasında ise öğrenciler akıllı telefonları mektup, bilgi ve haberleşme aracı gibi benzetmelerle tanımlamış ve akıllı telefonların haberleşme özelliğini vurgulamışlardır. Kişi ve kaynaklara ulaşma amacıyla en çok kullanılan araçlardan biri olan akıllı telefonlar, güncel teknolojik gelişmelerle birlikte sadece iletişim aracı olmaktan çıksa da hala en çok kullanılan araç olma özelliğini korumaktadır. Hong, Chiu, ve Huang (2012) akıllı telefonların sosyal ilişkileri ve iletişimi arttırma firsatı sunması sebebiyle öğrenciler arasında popüler olduğunu bildirmişlerdir.

Akıllı telefonun bu özelliklerinin yanında dengeli kullanımı ve vazgeçilebilir olmasına ilişkin az sayıda metafor üretildiği görülmektedir. Katılımcıların yalnızca \%3,4'ü akıllı telefonların dengeli kullanılması gerektiğini ve vazgeçilebilir olduğunu bildirmiştir. Benzer şekilde Polat'ın (2018) öğretmen adaylarıyla yaptığı metafor çalışması sonucunda, katılımcılarının \%10,8'inin bilinçli kullanım sağladığı görülmüsşür. Öğrencilerin akıllı telefonlarını zorunlu ve bağımlılık yaratıcı bir araç olarak algılamaları yüksek olmasına rağmen, dengeli kullanım konusunda düşük bir farkındalıkları olduğu söylenebilir. Vazgeçilebilir bir araç olarak telefon teması altında ise meyve suyu metaforunun kullanıldığ görülmüş̧ür.

Ayrıca öğrencilerin akıllı telefonlara ilişkin metaforlar anlamlarına göre olumlu, olumsuz ve hem olumlu hem de olumsuz olarak üç boyutta değerlendirilmiştir. Anlamlarına göre olumlu metaforlar $(n=199)$ çoğunlukta olup, olumsuz $(n=6)$ ve hem olumlu hem olumsuz metaforlar $(n=3)$ daha az sayıda bulunmuştur. Ulaşılan bu sonuç ilgili çalışmaların sonuçlarıyla paralellik göstermektedir (Çelik, Yılmaz ve Pazarlığlu, 2010; Saraç, 2019; Şenel, 2016). Öğrencilerin akıllı telefonlarını günlük hayatlarını kolaylaştırıcı, eğlenceli ve işlevsel bulduklarını söylemek mümkündür. Ulaşılan bu sonuçla öğrencilerin teknoloji ve akıllı telefon kullanımlarını faydalı ve işlevsel buldukları söylenebilir.

$\mathrm{Bu}$ çalışmada eğitim fakültesi öğrencilerinin akıllı telefonlara ilişkin algıları metafor analizi ile incelenmiş̧ir. Bulgular dikkate alındığında, öğrencilerin metaforlarından yola çıkarak oluşturulan temalarda sadece bağımlılık yönünün ön plana çıktığı görülmektedir. Bunun yanında akıllı telefonların kullanımının fiziksel ya da psikolojik sağlık üzerindeki etkileri, akademik yaşamdaki etkileri gibi konulara ilişkin metaforlar üretilmediği görülmektedir. Bu çalışmada eğitim fakültesi öğrencilerinin 
akıllı telefonlara ilişkin algıları metafor analizi ile incelenmiştir. Bulgular dikkate alındığında, öğrencilerin metaforlarından yola çıkarak oluşturulan temalarda sadece bağımlılık yönünün ön plana çıktığ1 görülmektedir. Bunun yanında akıllı telefonların kullanımının fiziksel ya da psikolojik sağlık üzerindeki etkileri, akademik yaşamdaki etkileri gibi konulara ilişkin metaforlar üretilmediği görülmektedir. Öğrencilerin akıllı telefonlara ilişkin metaforlarının özellikle ihtiyaç ve zorunluluk kavramları etrafında yoğunlaşması da dikkat çekicidir. Bunun yanında bilgi edinme, eğlence, sosyal destek ve iletişim gibi alanlardaki etkilerine de vurgu yapılmıştır. Araştırma sonuçlarından yararlanılarak öğrencilerin özellikle akıllı telefonların aşırı kullanımına bağlı olarak oluşabilecek sağlık sorunları, akıllı telefonlar aracılığı ile erişilen internete dayalı uygulama ve sosyal medyanın etkisi ve ilişkiler üzerindeki etkileri gibi konularda psikososyal eğitim programları düzenlenebilir. Araştırmacılar açısından ise yapılacak çalışmaların akıllı telefona yönelik algılar ile sağlık, başarı, kişiler arası ilişkilerin niteliği, gibi değişkenler çerçevesinde şekillenmesi önerilmektedir. Bunun yanında çalışmalar akıllı telefon kullanımında cinsiyetler arası farklı1ıklar da ele alınabilir. Mevcut araştırmanın en temel sınırlılığı nicel veriler ile desteklenmemiş olmasıdır. Bir diğer sınırlılık olarak da bu çalışmanın bir vakıf üniversitesindeki öğretmen adaylarından oluşmuş olması düşünülmektedir. Bu sinırlılıklar göz önünde bulundurularak, genellenebilir çalışmalar için nicel verilere yer verilmesi ve farklı fakültelerdeki öğrencilerle erişilerek örneklem oluşturulması da önerilmektedir.

\section{Kaynakça}

Adnan, M., \& Gezgin, D. M. (2016). Modern çağın yeni fobisi: Üniversite öğrencileri arasında nomofobi prevalansı. Ankara Üniversitesi Eğitim Bilimleri Fakültesi Dergisi,49(1), 141158.https://doi.org/10.1501/Egifak_0000001378

Altundağ, Y., \& Bulut, S. (2017). Aday Sınıf öğretmenlerinde problemli akıllı telefon kullanımının İncelenmesi. Abant İzzet Baysal Üniversitesi Ĕgitim Fakültesi Dergisi, 17(4), 1670-1682. https://doi.org/10.17240/aibuefd.2017.17.32772-363958

Baker, C., Wuest, J., \& Stern, P. N. (1992). Method slurring: The grounded theory/phenomenology example. Journal of Advanced Nursing, 17(11), 1355-1360. DOI: 10.1111/j.13652648.1992.tb01859.x

Baltac1, A. (2017). Nitel veri analizinde Miles-Huberman modeli. Ahi Evran Üniversitesi Sosyal Bilimler Enstitüsü Dergisi, 3(1), 1-14. https://dergipark.org.tr/tr/download/article-file/318527 adresinden erişilmiştir.

Bragazzi, N. L., \& Del Puente, G. (2014). A proposal for including nomophobia in the new DSMV. Psychology Research and Behavior Management, 7, 155-160. doi: 10.2147/PRBM.S41386

Csibi, S., Griffiths, M. D., Demetrovics, Z., \& Szabo, A. (2019). Analysis of problematic smartphone use across different age groups within the 'components model of addiction'. International Journal of Mental Health and Addiction, 1-16. https://doi.org/10.1007/s11469-019-00095-0.

Çelik, H. E., Yılmaz, V., \& Pazarlığlu, M. V. (2010). Teknoloji kabul modeli ve bir uygulama. Finans Politik ve Ekonomik Yorumlar, 47(540), 35-44. https://doi.org/10.17755/esosder.09008

De-Sola, J., Talledo, H., de Fonseca, F. R., \& Rubio, G. (2017). Prevalence of problematic cell phone use in an adult population in Spain as assessed by the mobile phone problem use scale (MPPUS). PLoS One, 12(8), 1-17.https://doi.org/10.1371/journal.pone.0181184

Dixit, S., Shukla, H., Bhagwat, A., Bindal, A., Goyal, A., Zaidi, A. K., \& Shrivastava, A. (2010). A study to evaluate mobile phone dependence among students of a medical college and associated hospital of central India. Indian Journal of Community Medicine: Official Publication of Indian Association of Preventive \& Social Medicine, 35(2), 339-341. https://doi.org/10.4103/09700218.66878

Ekici, G. (2016). Öğretmen adaylarını" bilgisayar" kavramına ilişkin metaforik algıları. Gaziantep University Journal of Social Sciences, 15(3), 755-781.DOI: 10.21547/jss.256704

Erdem, H., Türen, U., \& Kalkın, G. (2016). Üniversite öğrencilerinde mobil telefon yoksunluğu korkusunun (Nomofobi) akademik başarıya etkisi. Süleyman Demirel Üniversitesi Dergisi, 21(3),923-936.https://iibfdergi.sdu.edu.tr/assets/uploads/sites/352/files/yil-2016-cilt-21-sayi-3yazi11-01082016.pdf adresinden erişilmiştir. 
Erdem, H., Türen, U., \& Kalkın, G. (2017). Mobil telefon yoksunluğu korkusu (nomofobi) yayılımı: Türkiye'den üniversite öğrencileri ve kamu çalışanları örneklemi, Bilişim Teknolojileri Dergisi, 10(1), 1-12. https://dergipark.org.tr/tr/pub/gazibtd/issue/27536/289670 adresinden erişilmiştir.

Gezgin, D. M., Hamutoğlu, N. B., Samur, Y., \& Yıldırım, S. (2018). Genç nesil arasında yaygınlaşan bir bağımlılık: Akıllı telefon bağımlılı̆̆ının cinsiyet, akademik başarı ve mobil oyun oynama değiş̧kenleri açısından incelenmesi. Educational Technology Theory and Practice, 8(2), 212231. https://doi.org/10.17943/etku.397112.

Gezgin, D. M., Şumuer, E., Arslan, O., \& Yıldırım, S. (2017). Nomophobia prevalence among preservice teachers: A case of trakya university. Trakya Üniversitesi Ĕ̈itim Fakültesi Dergisi, 7(1), 86-95. https://dergipark.org.tr/tr/download/article-file/270323 adresinden erişilmiştir.

Grant, I., \& O’Donohoe, S. (2007). Why young consumers are not open to mobile marketing communication. International Journal of Advertising, 26(2), 223-246. https://doi.org/10.1080/10803548.2007.11073008

Guneyli, A., \& Özkul, A. (2013). Turkish language and history candidate teachers' use of metaphors in their perception of computer. Eurasian Journal of Educational Research, 53,(A), 185-204. https://www.ejer.com.tr/public/assets/catalogs/0748451001556011213.pdf\#page=187 adresinden erişilmiştir.

Hawi, N. S., \& Samaha, M. (2016). To excel or not to excel: Strong evidence on the adverse effect of smartphone addiction on academic performance. Computers \& Education, 98, 81-89. https://doi.org/10.1016/j.compedu.2016.03.007

Horwood, S., \& Anglim, J. (2019). Problematic smartphone usage and subjective and psychological well-being. Computers in Human Behavior, 97, 44-50. https://doi.org/10.1016/j.chb.2019.02.028

Hootsuite. (2018). Global digital report 2018. https://digitalreport.wearesocial.com/ adresinden 11 Aralık 2019 tarihinde erişilmiştir.

Hong, F. Y., Chiu, S. I., \& Huang, D. H. (2012). A model of the relationship between psychological characteristics, mobile phone addiction and use of mobile phones by Taiwanese university female students. Computers in Human Behavior, 28(6), 2152-2159. https://doi.org/10.1016/j.chb.2012.06.020

James, D., \& Drennan, J. (2005, December). Exploring addictive consumption of mobile phone technology. In Australian And New Zealand Marketing Academy Conference, Perth, Australia.

Kahyaoglu, Sut., Kurt, S., Uzal, O., \& Ozdilek, S. (2016). Effects of smartphone addiction level on social and educational life in health sciences students. Eurasian Journal of Family Medicine, 5(1), 13-19. http://ejfm.trakya.edu.tr/userfiles/2016/April/3-hatice-sut.pdf adresinden erişilmiştir.

Karaçam, S., \& Aydın. F. (2011). Ortaokul öğrencilerinin teknoloji kavramına ilişkin algılarının metafor analizi. Gaziantep University Journal of Social Sciences, 13(2), 545-572. https://dergipark.org.tr/en/download/article-file/223209 adresinden erişilmiştir.

Kibona, L., \& Mgaya, G. (2015). Smartphones' effects on academic performance of higher learning students. Journal of Multidisciplinary Engineering Science and Technology, 2(4), 777-784. http://www.jmest.org/wp-content/uploads/JMESTN42350643.pdf adresinden erişilmiştir.

King A.L.S., Valença A.M., Silva A.C., Sancassiani, F., Machado, S., \& Nardi, A.E. (2014). "Nomophobia": Impact of cell phone use interfering with symptoms and emotions of individuals with panic disorder compared with a control group. Clinical Practice and Epidemiology in Mental Health, 10, 28-35.doi: 10.2174/1745017901410010028

Konan, N., Durmuş, E., Ağıroğlu, A. B., \& Türkoğlu, D. (2018). The relationship between smartphone addiction and perceived social support of university students'. International Online Journal of Educational Sciences, 10(5), 244-259. http://dx.doi.org/10.15345/iojes.2018.05.016

Ksinan, A. J., Mališ, J., \& Vazsonyi, A. T. (2019). Swiping away the moments that make up dull day: Narcissism, boredom, and compulsive smartphone use. Current Psychology, 1-10. https://doi.org/10.1016/j.paid.2019.06.005

Kuss, D. J., \& Griffiths, M. D. (2011). Online social networking and addiction-a review of the psychological literature. International Journal of Environmental Research and Public Health, 8(9), 3528-3552.doi: 10.3390/ijerph8093528 
Kwon, M., Kim, D. J., Cho, H., \& Yang, S. (2013). The smartphone addiction scale: development and validation of a short version for adolescents. PloS one, 8(12), https://doi.org/10.1371/journal.pone.0083558

Kwon, M. S., Yoon, O. S., Noh, G. Y., Chun, J., \& Han, S. (2017). Smartphone addiction level and smartphone use expectation in adults. International Information Institute (Tokyo). Information, 20(8B), 6003-6010. doi: 10.1556/2006.4.2015.037

Lee, C., \& Lee, S.-J. (2017). Prevalence and predictors of smartphone addiction proneness among Korean adolescents. Children and Youth Services Review, 77, 10-17. https://doi.org/10.1016/j.childyouth.2017.04.002

Lee, Y. K., Chang, C. T., Lin, Y., \& Cheng, Z. H. (2014). The dark side of smartphone usage: Psychological traits, compulsive behavior and technostress. Computers in Human Behavior, 31, 373-383. https://doi.org/10.1016/j.chb.2013.10.047

Lemola, S., Perkinson-Gloor, N., Brand, S., Dewald-Kaufmann, J. F., \& Grob, A. (2015). Adolescents' electronic media use at night, sleep disturbance, and depressive symptoms in the smartphone age. Journal of Youth and Adolescence, 44(2), 405-418. https://doi.org/10.1007/s10964-014$\underline{0176-\mathrm{x}}$

Lepp, A., Barkley, J. E., \& Karpinski, A. C. (2015). The relationship between cell phone use and academic performance in a sample of US college students. Sage Open, 5(1). 19.https://doi.org/10.1177/2158244015573169

Lepp, A., Barkley, J. E., Sanders, G. J., Rebold, M., \& Gates, P. (2013). The relationship between cell phone use, physical and sedentary activity, and cardiorespiratory fitness in a sample of US college students. International Journal of Behavioral Nutrition and Physical Activity, 10(79). DOI: $10.1186 / 1479-5868-10-79$

Lin, Y. H., Chang, L. R., Lee, Y. H., Tseng, H. W., Kuo, T. B., \& Chen, S. H. (2014). Development and validation of the smartphone addiction inventor, SPAI. PloS one, 9(6), e98312. doi: 10.1371/journal.pone.0098312

Ling, R.S. (2004). Mobile connection. The cell phone's impact on society. California: Morgan Kaufmann Publishers.

Mascheroni, G., \& Ólafsson, K. (2016). The mobile Internet: Access, use, opportunities and divides among European children. New Media \& Society, 18(8), 1657-1679. DOI: $10.1177 / 1461444814567986$

Mendoza, J. S., Pody, B. C., Lee, S., Kim, M., \& McDonough, I. M. (2018). The effect of cellphones on attention and learning: The influences of time, distraction, and nomophobia. Computers in Human Behavior, 86, 52-60. https://doi.org/10.1016/j.chb.2018.04.027

Miles, M, B., \& Huberman, A. M. (1994). Qualitative data analysis: An expanded Sourcebook. (2nd ed). California: Sage.

Onat Kocabıyık, O. (2016). Olgubilim ve gömülü kuram: Bazı özellikler açısından karşılaştırma. Trakya Üniversitesi Eğitim Fakültesi https://dergipark.org.tr/en/pub/trkefd/issue/21483/230242 adresinden erişilmiştir.

Öz, H. \& Tortop, H. S. (2018). Üniversite okuyan genç yetişkinlerin mobil telefon yoksunluğu korkusu (nomofobi) ile kişilik tipleri arasındaki ilişkinin incelenmesi, E-Journal of New Media / Yeni Medya Elektronik Dergi, 2(3), 146-159.https://dergipark.org.tr/tr/download/article-file/513993 adresinden erilişilmiştir.

Polat, M. (2018). Öğretmen adaylarının “Akıllı Telefon”a yönelik metaforik algıları: Yoksa Davis en başından beri haklı miydı?. Online Journal of Technology Addiction \& Cyberbullying, 5(2), 88105. https://dergipark.org.tr/en/download/article-file/612793 adresinden erişilmiştir.

Richardson, M., Hussain, Z., \& Griffiths, M. D. (2018). Problematic smartphone use, nature connectedness, and anxiety. Journal of Behavioral Addictions, 7(1), 109-116. DOI: 10.1556/2006.7.2018.10

Saraç, H. (2019). Ortaokul 8.sınıf öğrencilerinin akıllı tahta ve cep telefonu hakkında görüşleri: Metafor analizi çalışması. Pamukkale Üniversitesi Eğitim Fakültesi Dergisi, 45(45), 99-115. doi: 10.9779/PUJE.2018.224

SecurEnvoy (2012, Feb 2). 66\% of the population suffer from Nomophobia the fear of being without their phone. https://www.securenvoy.com/blog/2012/02/16/66-of-the-population-suffer-fromnomophobia-the-fear-ofbeing-without-their-phone/. 18 Şubat 2020 tarihinde erişilmiştir. 
Shaw, H., Ellis, D. A., \& Ziegler, F. V. (2018). The Technology Integration Model (TIM). Predicting the continued use of technology. Computers in Human Behavior, 83, 204214.https://doi.org/10.1016/j.chb.2018.02.001

Sırakaya, M. (2018). Ön lisans öğrencilerinin nomofobi düzeylerinin akıllı telefon kullanım durumlarına göre incelenmesi. Mersin Üniversitesi Ĕ̈itim Fakültesi Dergisi, 14(2), 714-727. https://doi.org/10.17860/mersinefd.359458

Škařupová, K., Ólafsson, K., \& Blinka, L. (2016). The effect of smartphone use on trends in European adolescents' excessive Internet use. Behaviour \& Information Technology, 35(1), 68-74. https://doi.org/10.1080/0144929X.2015.1114144

Sohn, S., Rees, P., Wildridge, B., Kalk, N. J., \& Carter, B. (2019). Prevalence of problematic smartphone usage and associated mental health outcomes amongst children and young people: a systematic review, meta-analysis and GRADE of the evidence. BMC psychiatry, 19(1), 1-10. https://doi.org/10.1186/s12888-019-2350-x

Spitzer, M. (2015). M-Learning? When it comes to learning, smartphones are a liability, not an asset. Trends in Neuroscience and Education, 4(4), 87-91. DOI:10.1016/J.TINE.2015.11.004

Statista. (2018). Number of smartphone users worldwide from 2015 to 2020 (in billions). 18 Şubat 2020 tarihinde erişilmiştir. https://www.statista.com/statistics/274774/forecast-of-mobile-phoneusers-worldwide/

Statista (2019). Number of smartphone users worldwide from 2016 to 2021 (in billions). 18 Şubat 2020 tarihinde erişilmiştir. https://www.statista.com/statistics/330695/number-of-smartphone-usersworldwide/

Şahin, Ş. \& Baturay, M. H. (2013). Ortaöğretim öğrencilerinin internet kavramına ilişkin algılarının değerlendirilmesi: Bir metafor analizi çalışması. Kastamonu Ĕ̈itim Dergisi, 21(1), 177-192. https://app.trdizin.gov.tr/publication/paper/detail/TVRRMk1UTXpNdz09 $\quad$ adresinden erişilmiștir.

Şenel, M. (2016). İngilizce öğretmenliği bölümü öğrencilerinin cep telefonu ile ilgili algılarının metaforlar aracılığılla analizi. Kastamonu Üniversitesi Kastamonu Ĕ̈itim Dergisi, 24(4), 17491764. https://dergipark.org.tr/en/pub/kefdergi/issue/27734/322844 adresinden erişilmiştir.

Tavolacci, M. P., Meyrignac, G., Richard, L., Dechelotte, P., \& Ladner, J. (2015). Problematic use of mobile phone and nomophobia among French college students Marie-Pierre Tavolacci. European Journal of Public Health, 25(3), 172-188. DOI: 10.1093/eurpub/ckv172.088

Tindell, D. R., \& Bohlander, R. W. (2012). The use and abuse of cell phones and text messaging in the classroom: A survey of college students. College Teaching, 60(1), 1-9. https://doi.org/10.1080/87567555.2011.604802

Türkiye İstatistik Kurumu (2019). Hanehalk1 bilişim teknolojileri kullanım araştırması. http://www.tuik.gov.tr/PreTablo.do?alt_id=1028 adresinden erişilmiştir.

Valk, J. H., Rashid, A. T., \& Elder, L. (2010). Using mobile phones to improve educational outcomes: An analysis of evidence from Asia. The International Review of Research in Open and Distributed Learning, 11(1), 117-140. DOI: https://doi.org/10.19173/irrodl.v11i1.794

Wang, J. L., Wang, H. Z., Gaskin, J., \& Wang, L. H. (2015). The role of stress and motivation in problematic smartphone use among college students. Computers in Human Behavior, 53, 181188. DOI:10.1016/j.chb.2015.07.005

We are social (2019, Jan 30). Digital 2019 in Turkey. https://wearesocial.com/global-digital-report-2019 adresinden erişilmiştir.

We are social (2020, Feb 18). Digital 2020: Turkey. https://datareportal.com/reports/digital-2020-turkey adresinden erişilmiştir.

Yang, Z., Asbury, K. \& Griffiths, M. D. (2018). Do chinese and british university students use smartphones differently? A cross-cultural mixed methods study. International Journal of Mental Health and Addiction, 17, 644-657. https://doi.org/10.1007/s11469-018-0024-4.

Yıldırım, A. \& Şimşek, H. (2013). Sosyal bilimlerde nitel araştırma yöntemleri. Ankara: Seçkin Yayıncilik.

Yıldırım, C., Sumuer, E., Adnan, M., \& Yıldırım, S. (2016). A growing fear: Prevalence of nomophobia among Turkish college students. Information Development, 32(5), 1322-1331. doi:10.1177/0266666915599025 


\section{Extended Abstract}

\section{Introduction}

Smart phones have become indispensable tools in people's daily lives with their wide application options and mobile interaction opportunities (Statista, 2018). Technology brings various psychological consequences alongside its widespread usage (Shaw, Ellis and Ziegler, 2018). In addition to the convenience they provide, smartphones can cause mental health problems such as stress (Hawi and Samaha, 2016), narcissism (Ksinan, Mališ and Vassonyi, 2019) and low self-esteem (Kuss and Griffiths, 2011). In a metaphor study, the most expressed metaphors were the brain, television, book, cigarette, encyclopaedia, library, universal information box, friend, mobile phone and the world (Ekici, 2016). In the light of the literature review, it is important to determine university student's perceptions towards smart phones, considering their developmental period and their interactions with the digital world. The main aim of this research is to examine the perceptions of students at the Faculty of Education in Ankara towards smart phones through metaphors.

\section{Methodology}

A qualitative study was conducted using metaphors to explore the perceptions of the participants towards smart phones. Phenomenology design, one of the qualitative research designs, was used in the study. The study group consists of 208 university students studying at Faculty of Education of a foundation university in Ankara in the spring semester of 2018-2019. 175 of the participants (84.1\%) were women and $33(15.9 \%)$ were men. Convenience sampling method was used in data collection for easy accessibility of students. Before filling out the forms, the students were explained the purpose of the research and they were given approximately 20 minutes to fill the form. Students were asked to complete the sentence "Smart phone is like.....because ......". Content analysis was used to examine the data and to discover the concepts and connections.

\section{Findings and Discussion}

The perceptions of education faculty students between the ages of 18-33 about smart phones were examined using metaphor analysis. 208 metaphors about smart phones generated by participants which grouped under 9 conceptual categories as, telephone as an indispensable and compulsory tool, telephone as a facilitating and functional tool, telephone as an addictive tool, telephone as a source of entertainment, telephone as a mean of social support, telephone as a mean of information, telephone as a mean of communication and access, telephone should be used in a balanced way as a tool and telephone as a dispensable tool. Smart phones were mostly indispensable and essential for the students. Saraç (2018) indicated a similar result in his research about smart boards and mobile phones and stated that students perceive mobile phones as an indispensable tool.

The usage of smart phones as life-facilitating and functional was found to be a common perception among students. Another important result is that smartphones are perceived as an addictive tool. The concept of smartphone addiction has been examined in many studies and its importance is increasing in the literature. Studies states that the fear of mobile phone deprivation, defined as Nomophobia, is common among university students (Erdem et al., 2017; SecurEnvoy, 2012).

Considering the findings, the addiction aspect stands out in the themes created based on the students' metaphors. In addition, metaphors on subjects such as the effects of the use of smartphones on physical or psychological health and the effects in academic life are not generated. Based on the results of the research, psychoeducational programs can be carried on subjects such as health problems that may occur especially due to excessive use of smart phones, the effect of internet-based application and social media accessed via smart phones and its effects on relationships.

\footnotetext{
* Bu çalışmada bulunan yazarların katkı oranları: Hicran Çetin Gündüz \%40, Zeynep Kızıl Aslan \%30, Cansu Hazal Güçlü \%30
} 